doi: 10.32620/oikit.2019.83.01

УДК 629.735.33.02:

О. Д. Донець*, О. 3. Двейрін*,Є. Т. Василевський, $620.22-419.01$

С. А. Філь*, О. Г. Гребеніков**, А. М. Гуменний ${ }^{* *}$

\title{
Проектно-конструкторські особливості планеру регіонального пасажирського літака
}

\author{
* Державне підприємство «АНТОНОВ» \\ ** Національний аерокосмічний університет ім. М. Є. Жуковського \\ «Харківський авіаційний інститут»
}

Описано проектно-конструкторські особливості планера регіонального пасажирського літака, котрі були впроваджені на етапах створення сімейства літаків Ан-148/Ан-158. Наведено конструкторсько-проектні роботи щодо планера літака, які були спрямовані на реалізацію ідеології проектування планера, заснованої на принципі конструкції, що безпечно ушкоджується. Літаки Ан-148/Ан-158 спроектовані із застосуванням сучасних комп'ютерно інтегрованих систем проектування. Виконані роботи забезпечують аеропружну стійкість при всіх його конфігураціях і при всіх розрахункових умовах. При створенні сімейства регіональних пасажирських літаків у конструкції планера (фюзеляж, крило, пілони навіски силових установок і оперення) застосовано ряд нових конструктивно-технологічних рішень, зокрема: у фююеляжі розширено обсяг застосування композиційних матеріалів (КМ), включаючи балки підлоги й стійки їх кріплення до елементів конструкції фюзеляжу; відсік допоміжної силової установки виконаний повністю із КМ; кріплення обшивки до каркаса фрюзеляжу виконано за допомогою заклепок із компенсатором, що забезпечує високу якість зовнішньої поверхні та виключає необхідність фрезування головок заклепок після їхньої установки; каркас ліхтаря фрюзеляжу виготовлений методом зварювання, що суттєво спростило технологію його складання; застосовано двохопорну сполучену схему навіски і керування висуванням секцій передкрилка з використанням евольвентного зачеплення в приводах випуску-вбирання передкрилка по механізмах навішення у вигляді пари зубчасте колесо - зубчаста рейка; розроблено раціональну конструкцію кесона крила 3 теоретичною поверхнею подвійної кривизни, високою технологічністю і експлуатабельністю із забезпеченням живучості і високого ресурсу; розроблено семиланковий механізм випуску - вбирання закрилка, що забезпечує задану траєкторію висування закрилка; розроблено комбіновану конструкцію закрилка з металевою кесонною частиною, носовою й хвостовою частиною і дефлектором із КМ; застосовано покриття з молібдену, що підвищило зносостійкість високонавантажених деталей 3 титанових сплавів більш ніж в 20 раз; розроблено монолітну інтегральну конструкцію інтерцепторів і елеронів із КМ; розроблено раціональну конструкцію пілона навіски маршової силової установки із забезпеченням оптимальних характеристик жорсткості для досягнення заданих характеристик фрлатерної безпеки, широким застосуванням композитних матеріалів у хвостовій і носовій частині; розроблено конструкцію поясів із пресованих напівфабрикатів із двома закінцівками; розроблено інтегральну конструкцію руля напрямку і руля висоти із композиційних матеріалів.

Ключові слова: регіональний пасажирський літак, планер літака, конструкторськопроектні роботи, пасажирське, аварійно-рятувальне устаткування.

Проектування і конструювання регіонального пасажирського літака виконується відповідно до основних вимог льотної придатності літаків транспортної категорії [1].

Конструкція літака не повинна мати таких особливостей та частин, котрі створюють аварійні умови або $€$ ненадійними. Придатність таких частин і деталей має визначатися шляхом відповідних проектно-конструкторських робіт та експериментальних досліджень. 


\section{Конструкторсько-проектні роботи щодо планера}

Ідеологія проектування планера основана на принципі конструкції, що безпечно ушкоджується. Відповідно до даного принципу на підставі досвіду й випробувань виконано вибір раціональних матеріалів і технології виробництва, що забезпечують постійність якості конструкції планера. Розрахункові значення характеристик міцності матеріалів визначені 3 урахуванням зменшення ймовірності руйнування конструкції через мінливість властивостей матеріалів і впливу умов навколишнього середовища, таких, як температура, вологість і т. ін.

Забезпечена можливість огляду елементів конструкції для проведення періодичного контролю, в тому числі неруйнівного інструментального.

Літак спроектований таким чином, що при всіх його конфрігураціях і при всіх розрахункових умовах не виникає аеропружної нестійкості.

Розроблення конструкції планера виконано в CAD системі тривимірного параметричного моделювання та системі керування даними про виріб (рисунок 1). Для розрахункової оптимізації й інженерних аналізів використано скінченно-елементну CAD/CAE системи MSC.Software, Фронт та інші системи.

Літаки Ан-148/Ан-158 - це перші літаки ДП «АНТОНОВ», спроектовані у комп'ютерних інтегрованих системах проектування із застосуванням зазначених програмних продуктів (рисунок 2).

Сутність процесу розроблення в комп'ютерних інтегрованих системах проектування полягає в тому, що на концептуальній стадії (технічна пропозиція й ескізний проект) закладаються характеристики майбутнього виробу [2]. На стадії робочого проектування створюється конструкція на базі єдиної цифрової моделі конструкції виробу, що задовольняє цим характеристикам. На стадії виготовлення й випробування дослідного зразка проводять льотні й наземні випробування для одержання й підтвердження характеристик 3 метою одержання сертифіката виробу. За результатами випробувань уточняється цифрова модель і електронні креслення для серійного випуску виробу.

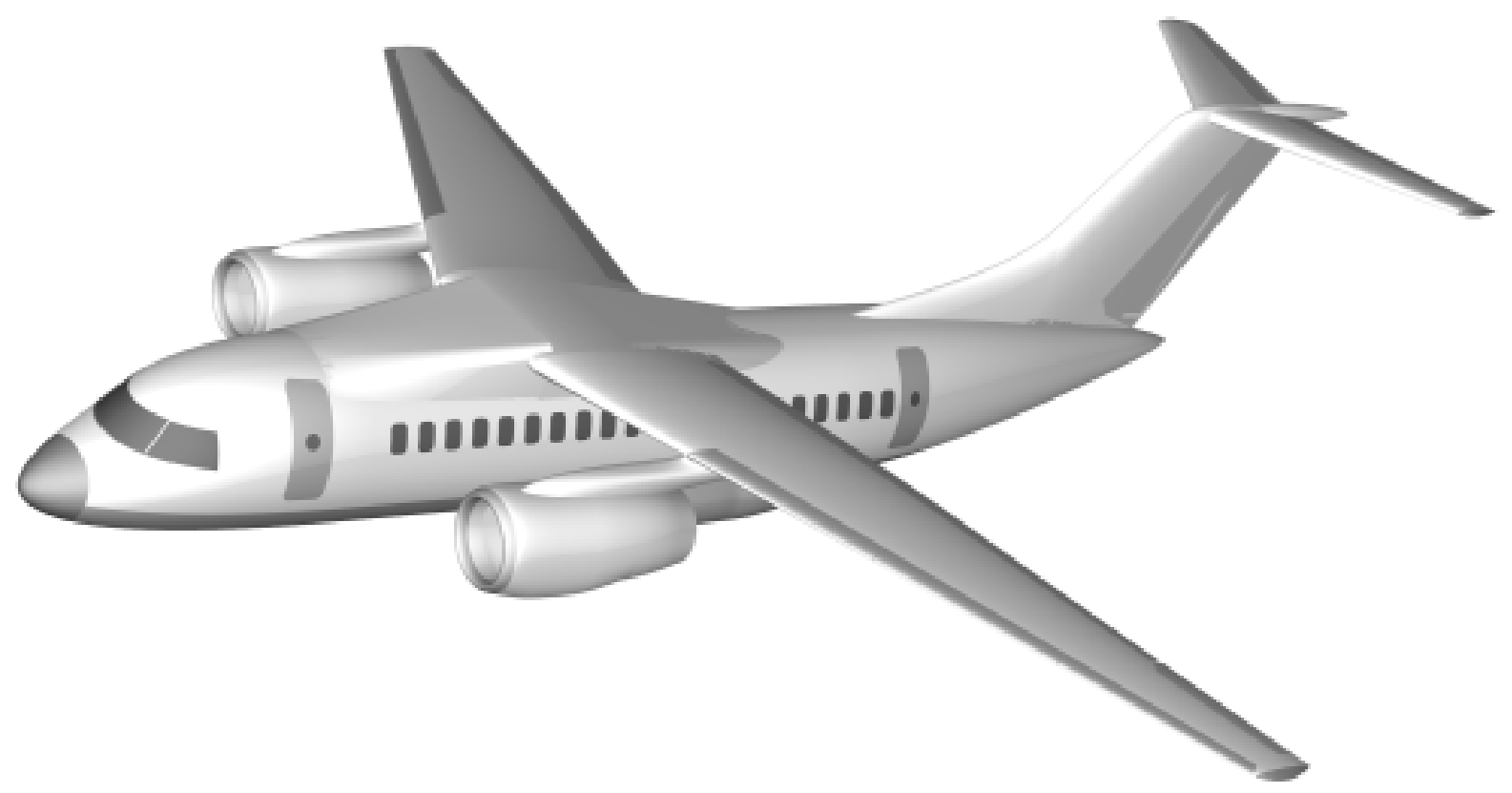

Рисунок 1 - Майстер-геометрія регіонального пасажирського літака 


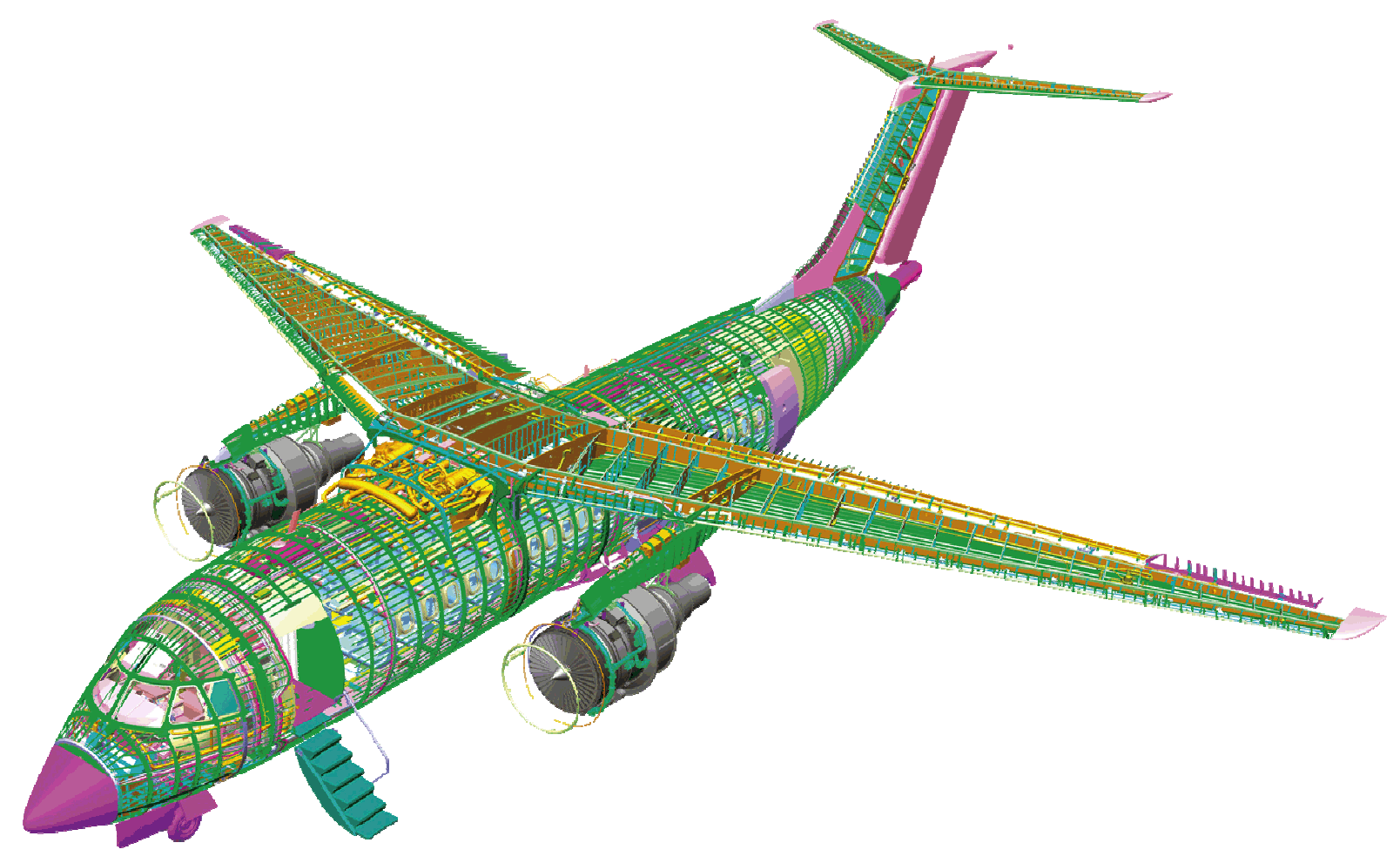

Рисунок 2 - Фрагмент моделі повного визначення літака Ан-148

При такому підході на концептуальній стадії створюється цифровий віртуальний прототип виробу для розрахункового комп'ютерного визначення й контролю характеристик систем. На стадії робочого проектування проводять уточнення параметрів моделі через параметри і характеристики розроблюваної конструкції виробу. На стадії виготовлення дослідного зразка здійснюють коректування моделі і уточнення іiї характеристик, а також льотні і наземні випробування в обмеженому обсязі для одержання й підтвердження характеристик для сертифікації виробу. На базі відкоректованої моделі уточняють електронні креслення для серійного випуску виробів.

У силовій конструкції планера неможливо уникнути зон із підвищеним рівнем напруг - так званих нерегулярних зон. До таких зон відносять поперечні стики панелей і обшивок, кінцівки стрингерів, усілякі вирізи, перестикування, посилення у вигляді накладок і т. ін. (рисунок 3). Підвищена концентрація напруг приводить до необхідності значного зниження напруг у цих зонах або до ранньої появи тріщин відносно регулярних зон. Проектування таких зон виконувалося на базі скінченно-елементної оптимізації на моделях різного рівня глибини подробиць моделювання з використанням досвіду попередніх конструкторських рішень.

Залежно від ступеня подробиць моделювання конструкції й розмірів частини конструкції, яка моделювалася, було реалізовано три рівні моделювання.

Рівень загального напружено-деформованого стану (моделювалася вся конструкція агрегату планера). Дана модель використовувалася для розрахунків розподілу основних силових потоків в агрегаті, розрахунків загального напружено-деформованого стану (НДС), оптимізаційних завдань щодо розподілу жорсткостей і мас конструкції та ін. 


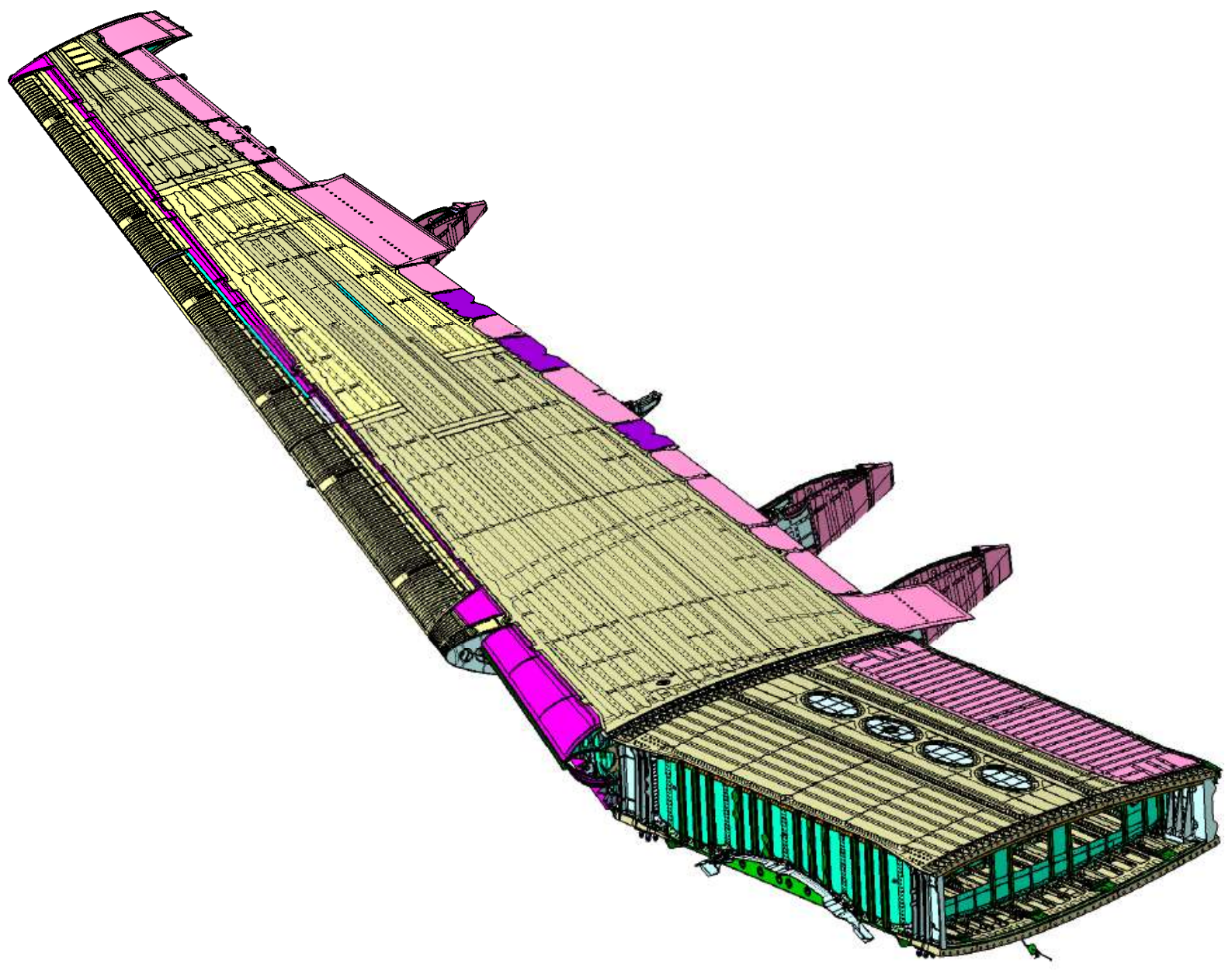

Рисунок 3 - Фрагмент моделі конструктивно-силової схеми центроплана та консольної частини крила літака Ан-148

Рівень моделювання місцевого НДС у відсіках агрегатів - другий рівень моделювання. Такі моделі використовували для розрахунку місцевого НДС у більш точній постановці, визначення несучої здатності конструкції, оцінювання живучості конструкції, одержання даних для уточненого аналізу ресурсних характеристик.

На третьому рівні моделювалися вузли, фрітинги, ділянки стиків і елементів конструкції (рисунок 4). При цьому виконувалися розрахунки місцевого НДС на найбільш детальному рівні, визначалися контактні напруги, розподіл зусиль щодо кріплення, виконувався аналіз характеристик втоми і живучості.

При цьому вся геометрична інформація була отримана з моделі майстергеометрії. Використання систем MSC.Software дозволило виконати інженерний аналіз у вигляді багатодисциплінарного комплексного аналізу на базі взаємозалежних продуктів для вирішення задач аналізу в різних областях (навантажень, статичної й втомної міцності, живучості, аеропружності та ін.) при забезпеченні сумісності за даними і можливості використання тих самих моделей або запозичення даних із різних моделей. При цьому суттєво підвищилася якість спроектованих виробів при одночасному прискоренні процесу розроблення конструкції, з'явилася можливість створювати конструкцію з мінімальною масою, яка у великому ступені відповідає заявленим проектним параметрам. 

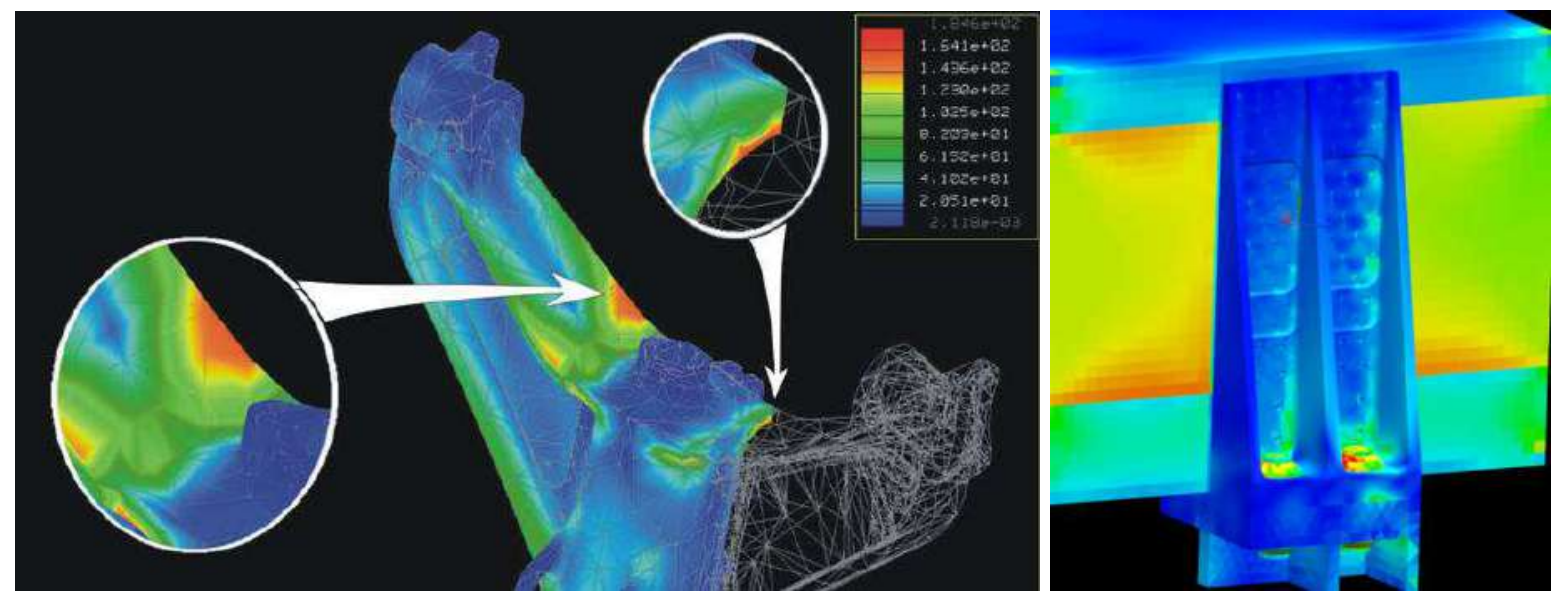

Рисунок 4 - Чисельні методи розрахунку місцевого напружено-деформованого стану

Сімейство літаків Ан-148-100/Ан-158 спроектовано і виготовлено у всекліматичному виконанні із дотриманням усіх вимог щодо антикорозійного захисту для цього виду виконання.

Планер літака складається з фюзеляжу, крила, пілонів навіски силових установок і оперення. У конструкції планера реалізовані нерегулярності 3 урахуванням максимальної нейтралізації концентрації напруг, реалізована концепція багатоколійної передачі навантаження із забезпеченням достатнього рівня залишкової міцності. Широко застосовані конструктивно-технологічні рішення, що підвищують ресурсні характеристики елементів конструкції кесона (кріплення натягом, різні види зміцнення, оптимальні посилення в зонах концентрації напруг) [2, 3, 4].

\section{Пасажирське устаткування літаків}

Пасажирське устаткування сімейства літаків Ан-148-100/Ан-158 призначено для створення комфортних умов перебування пасажирів на борту літака під час польоту й на землі. Крім декоративної і ергономічної функцій, облицювання інтер'єру захищають монтажі і устаткування літакових систем від ушкоджень і стороннього втручання. Облицювання також відіграють роль другої звукоізолюючої стінки, тому стики панелей ущільнені.

За компонуванням пасажирська кабіна літака ділиться на передній вестибюль, пасажирський салон і задній вестибюль. Принципову схему інтер'єру в базовому варіанті показано на рисунку 5.

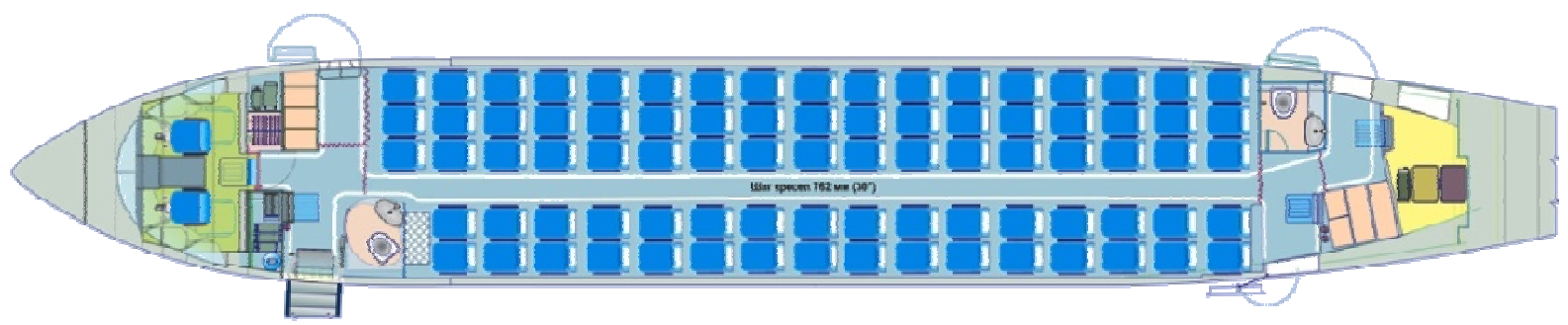

Рисунок 5 - Принципова схема інтер'єру в базовому варіанті для перевезення 83 пасажирів (крок крісел - 762 мм (30")) 
Для забезпечення рівня шуму і вібрації в салоні, що не перевищують нормованих значень, внутрішня поверхня фрюзеляжу покрита теплозвукоізоляцією (ТЗІ), а в зоні 28 - 39 шпангоутів додатково на обшивку фюзеляжу встановлюється самоклеюче вібропоглинаюче покриття. На облицювання пасажирського салону встановлена додаткова ТЗІ.

Пасажирський салон освітлюється відбитим світлом від люмінесцентних ламп, установлених у чотирьох поздовжніх коробах. Два верхні перебувають за центральною панеллю стелі, а два бічні - по бортах, на стику віконних панелей і панелей обслуговування.

Основними конструкційними матеріалами в інтер'єрі літака $є$ склопластики і тришарові панелі зі стільниковим заповнювачем із полімерного паперу.

Секції (модулі) стелі, багажних полиць, панелей обслуговування, віконні панелі, нижні панелі, буфети, гардероб збираються поза літаком з наступною установкою на фрюзеляжних вузлах кріплення, установлених по взаємопов'язаному оснащенню.

Як декоративно-оздоблювальні матеріали в інтер'єрі пасажирської кабіни застосовують лакофрарбове покриття (ЛКП) або, за бажанням замовника, захисно-декоративні плівки. Колірна схема оброблення може бути вибрана замовником літака.

Для зручності обслуговування літакових систем панелі обслуговування пасажирів, багажні полки й стельові панелі виконані відкидними, а віконні панелі і панелі нижні - легкозйомними.

Пасажирський салон літака в базовому компонуванні розрахований на розміщення 80 пасажирів в економічному класі із кроком крісел 30 дюймів (762 мм). По правому борту встановлені потрійні блоки крісел, по лівому подвійні. Ширина проходу на рівні підлокітників крісел - 483 мм. Типовий перетин інтер'єру пасажирського салону показано на рисунку 2.

По всій довжині пасажирського салону інтер'єр має однакову геометрію перетину, відповідну до теоретичного контуру інтер'єру, незважаючи на звуження фрюзеляжу у хвостовій частині. Агрегати і панелі інтер'єру салону мають модульну конструкцію, що забезпечує їхню взаємозамінність і простоту обслуговування.

Лицювальний комплекс інтер'єру включає такі конструктивно-технологічні і функціональні зони:

- стеля;

- багажні полки для ручної поклажі пасажирів;

- панелі обслуговування пасажирів;

- облицювання бічних коробів освітлення;

- віконне облицювання;

- панелі нижні;

- килимове покриття підлоги.

Стеля салону складається із центральних і бічних панелей. Центральні панелі містять у собі плафони освітлення і кріпляться за допомогою петель і замків. Замки відкриваються за допомогою ключа-шестигранника. Відкидаються панелі до правого борту, забезпечуючи доступ до огляду і обслуговуванню устаткування, установленого за стелею. При відкритті панелей необхідно притримувати їх руками, щоб уникнути поломок і ушкоджень.

Бічні панелі кріплять за допомогою напрямів-захватів і замків. За необхідності вони повністю знімаються. 


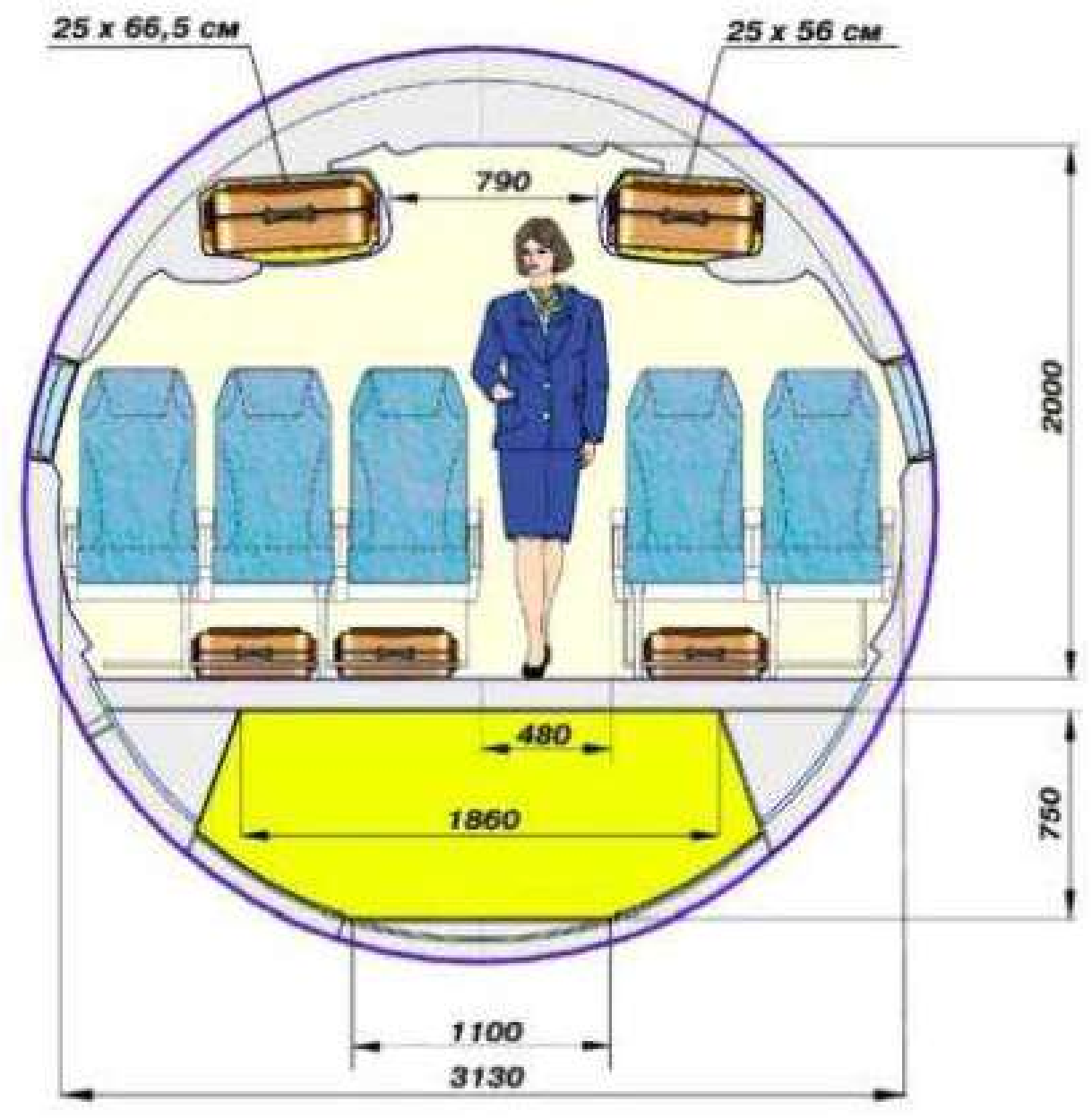

Рисунок 6 - Типовий перетин інтер'єру пасажирського салону

Між центральними і бічними панелями стелі виконані профрільовані канали для видування повітря із системи кондиціювання.

Багажні полки - закритого модульного типу, обсягом 4,1 м³, уміщають стандартний багаж $560 \times 450 \times 250$ мм, що відповідає вимогам Європейської асоціації авіаперевізників, і забезпечують обсяг 0,0512 м $^{2}$ або вагу 9,9 кг на пасажира в базовому компонуванні.

Полиці вміщають довгомірну поклажу довжиною до 2,1 м. Припустиме завантаження одного модуля полиці становить 72 кг.

Багажні полиці кріплять до фююзеляжу за допомогою кронштейнів і спеціальних вібропоглинаючих втулок, що дозволяє знизити вібрацію інтер'єру і додатково зменшити рівень шуму в салоні.

Щоб відкрити полицю, треба натиснути клавішу замка на стулці багажної полиці і забрати руку. Стулка сама відкриється під дією актуатора-демпфера. Закривається стулка вручну до защіпання замка.

Для огляду і обслуговування систем літака полиця може бути відкинута на осі кріплення. Для цього необхідно спочатку зняти верхні фрланці, відкрутивши гвинти викруткою, а потім за допомогою ключа-шестигранника викрутити осі навішення багажної полиці і, притримуючи руками, відкинути полицю вниз.

Під багажними полками встановлені панелі обслуговування пасажирів, на яких змонтовані світильники індивідуального освітлення, насадки індивідуальної вентиляції, кнопки виклику бортпровідника, інформаційні табло й радіодинаміки. 
Між панелями обслуговування над кожним рядом крісел установлені блоки 3 автоматичними аварійними кисневими масками. За бажанням замовника літака між панелями обслуговування можуть бути встановлені TV-монітори інформаційно-розважальної системи. Крім того, на панелях обслуговування встановлені світлові індикатори з нумерацією пасажирських місць.

Щоб відкинути панель обслуговування, необхідно в зазор між панеллю обслуговування і проставкою (у зоні замка по обидва боки) вставити плоский предмет (типу металевої лінійки) і натиснути на важіль замка до відкриття панелі.

Між панелями обслуговування і віконними панелями встановлені панелі облицювання бічних коробів освітлення салону. Для заміни ламп ці панелі легко відкидаються без застосування інструменту.

Віконні панелі виконані у вигляді модулів на три вікна. На панелях змонтовані сонцезахисні зсувні щитки (світлофрільтри), третя шибка і проміжна окантовка для зменшення шуму в салоні. Віконні панелі по верхній крайці кріпляться за допомогою пружинних затискачів, а по нижній крайці - за допомогою поворотних замків.

Панелі нижні закривають зону борту від віконних панелей до підлоги. Через поздовжні отвори в нішах нижніх панелей здійснюється відбір системою кондиціювання відпрацьованого повітря з пасажирської кабіни. Кріпляться панелі нижні по верхній крайці за допомогою пружинних затискачів, а по нижній крайці - за допомогою гвинтів.

Килим покриває всю площу підлоги салона й кріпиться до підлоги за допомогою липкої стрічки й профрілів-притисків по рейках кріплення крісел. Для забезпечення доступу до устаткування, встановленого в просторі під підлогою, центральна доріжка килимового покриття може скочуватися в рулон у будь-яку сторону. По бортах крайки килима піднімаються на нижні панелі на висоту ніші. Крім декоративної фрунції килими виконують роль додаткової теплозвукоізоляції.

Передній вестибюль розташований між кабіною екіпажу й пасажирським салоном i, залежно від варіанта компонування, може бути відділений від пасажирського салона шторою, туалетом по лівому борту й гардеробом по правому борту. Від кабіни екіпажу вестибюль відокремлюють етажерка «авіоніки» по лівому борту й гардероб членів екіпажу по правому борту.

Передній вестибюль $є$ одночасно робочою зоною бортпровідника, тут установлені його крісло й буфет. Зона буфету відділена поздовжньою шторою. Частина гардеробу по правому борту за бажанням замовника може бути обладнана додатковим буфетним модулем.

Облицювання й стеля вестибюля виконані з композиційних матеріалів на основі скловолокна й декоративно оброблені аналогічно 3 пасажирським салоном.

Підлога у вестибюлі покрита спеціальним антифрикційним вологостійким покриттям. Освітлюється вестибюль круглим плафоном, установленим на стелі.

Задній вестибюль розташований між пасажирським салоном і заднім багажним відсіком і відділений від салона туалетом по правому борту, шторою по проходу й перегородкою по лівому борту. Верхня прозора частина цієї перегородки виконана відкидною для полегшення завантаження й вивантаження хворих на ношах. Крім цього вона забезпечує прямий огляд пасажирського салона з місця бортпровідника. Щоб відкинути скло, необхідно 
відкрити замок у верхній частині скла, натиснувши пальцем на його кнопку, й, притримуючи скло, обережно вилучити його в крайнє нижнє положення.

Задній вестибюль, також, як і передній, $\epsilon$ робочою зоною для двох бортпровідників, тут також установлено два крісла й буфет. Зона буфету відділена поперечною шторою. Праворуч від крісла бортпровідника по правому борту встановлений контейнер для сміття.

Облицювання, стеля, декоративна обробка, покриття підлоги й освітлення заднього вестибюля такі ж, як і в передньому вестибюлі.

Буфети являють собою універсальні модулі із гніздами для розміщення змінного буфетного устаткування. Конструктивно буфети зібрані зі стільникових панелей. Усе устаткування в гніздах надійно закріплене поворотними замками для забезпечення необхідної безпеки на зльоті й посадці літака. Конструкція буфетів передбачає можливість розміщення устаткування в різних варіантах комплектації.

Максимальна комплектація переднього буфету містить:

- 2 контейнери стандарту ATLAS;

- 3 напіврозмірних візка стандарту ATLAS;

- 1 кавоварка (модель 416-0001-29 фірми B/E Aerospace);

- 2 конвекційних печі (модель DF-300 фрірми B/E Aerospace). відходів.

Також передній буфет обладнаний відкидним столиком і відсіком для

Максимальна комплектація заднього буфрету містить:

- 4 контейнери стандарту ATLAS,

- 2 напіврозмірних візка стандарту ATLAS,

- 2 повнорозмірних візка стандарту ATLAS,

- 2 кавоварки (модель 416-0001-29 фірми B/E Aerospace),

- 2 конвекційних печі (модель DF-1075 або DF-115 фірми B/E Aerospace).

Задній буфет також обладнаний відкидним столиком.

Водопостачання буфетів здійснюється з бака водопостачання літака. Бак заправляється через панель централізованого заправлення водою. Вода підходить до кавоварок. Кавоварки служать для готування кави й підігріву води, легко знімаються 3 постійно встановленої підставки. У конструкції буфретів передбачені невеликі бачки для зливу води, пролитої при експлуатації кавоварки. У міру наповнення ці бачки необхідно знімати й воду зливати (у туалет).

Печі конвекційні призначені для підігріву й зберігання їжі.

На вимогу покупця літак може поставлятися в різних компонуваннях (див. рисунки 7 - 12).

У розряд опціонів, що поставляються в рахунок комерційного навантаження, входять:

- штори,

- перегородки між класами,

- передній туалет,

- передній гардероб,

- задній додатковий буфет.

Передній гардероб має два варіанти виконання - просто гардероб і гардероб із буфетним модулем.

Задній додатковий буфет установлюють у передній частині заднього багажно-вантажного відсіку і може включати: 
- опціон 1: один напіврозмірний візок і 2 контейнери (ATLAS),

- опціон 2: 6 контейнерів (ATLAS).

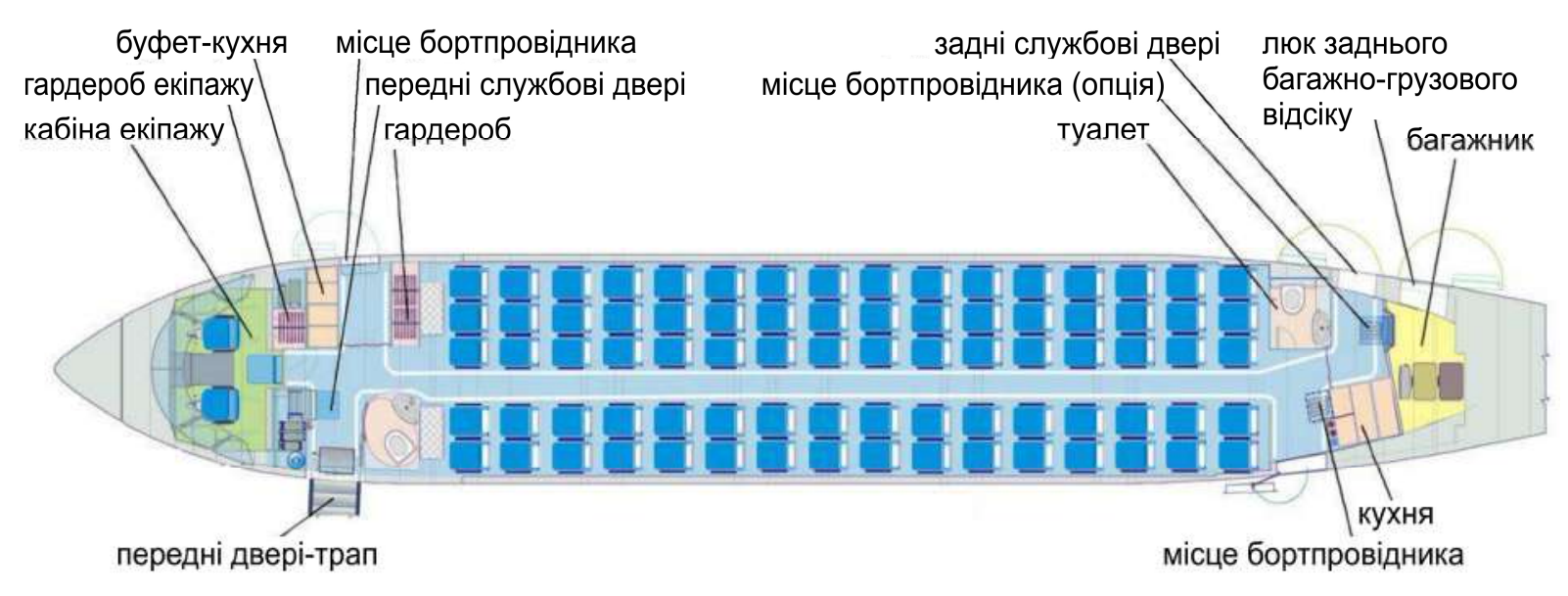

\section{Рисунок 7 - Компонування літака Ан-148 на 80 пасажирів (крок крісел - 762 мм (30"))}

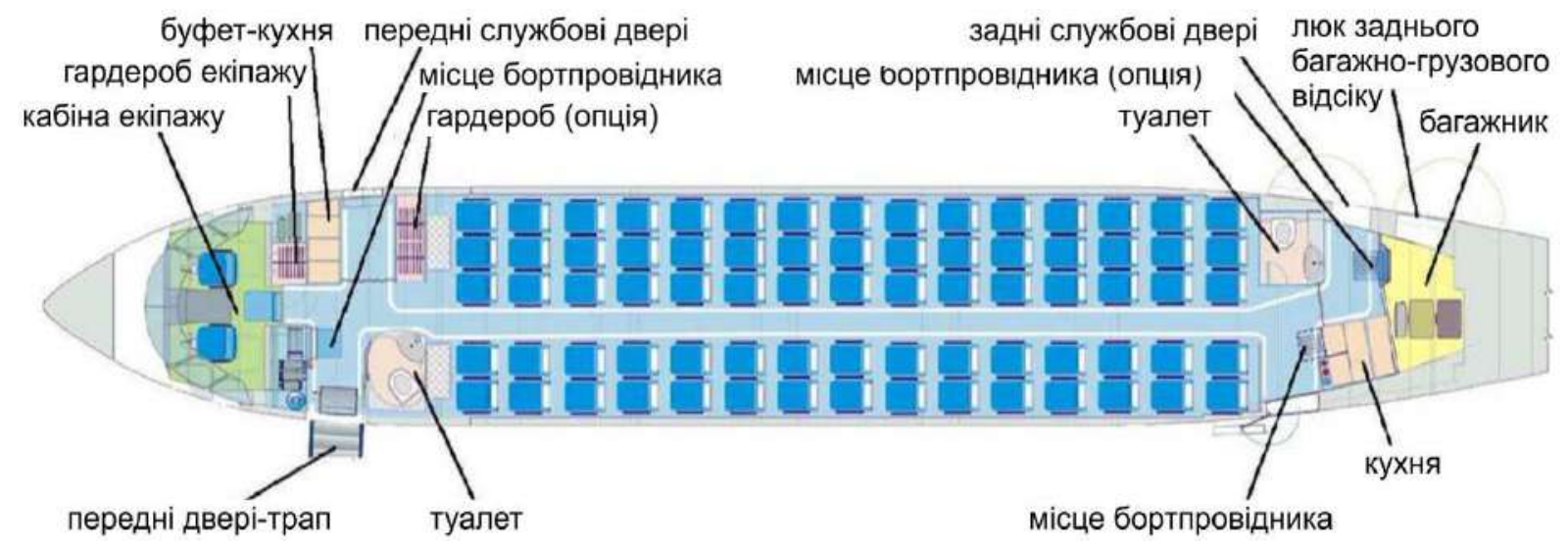

$$
\begin{aligned}
& \text { Рисунок } 8 \text { - Компонування літака Ан-148 на } 75 \text { пасажира } \\
& \text { (крок крісел - } 813 \text { мм (32")) }
\end{aligned}
$$

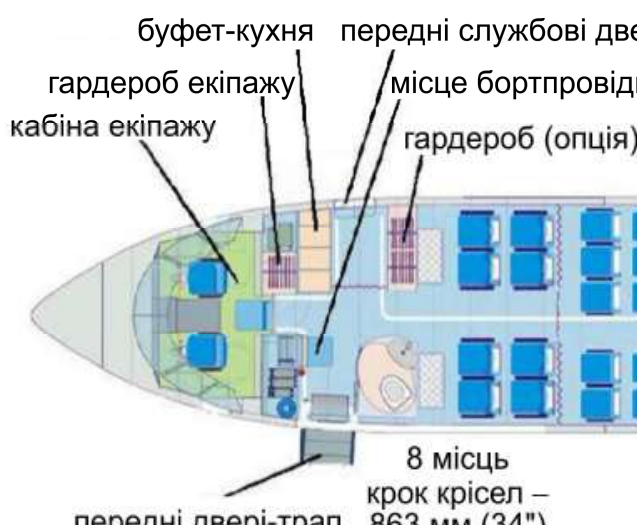

передні двері-трап 863 мм (34")

\section{Рисунок 9 - Компонування літака Ан-148 на 73 пасажира}



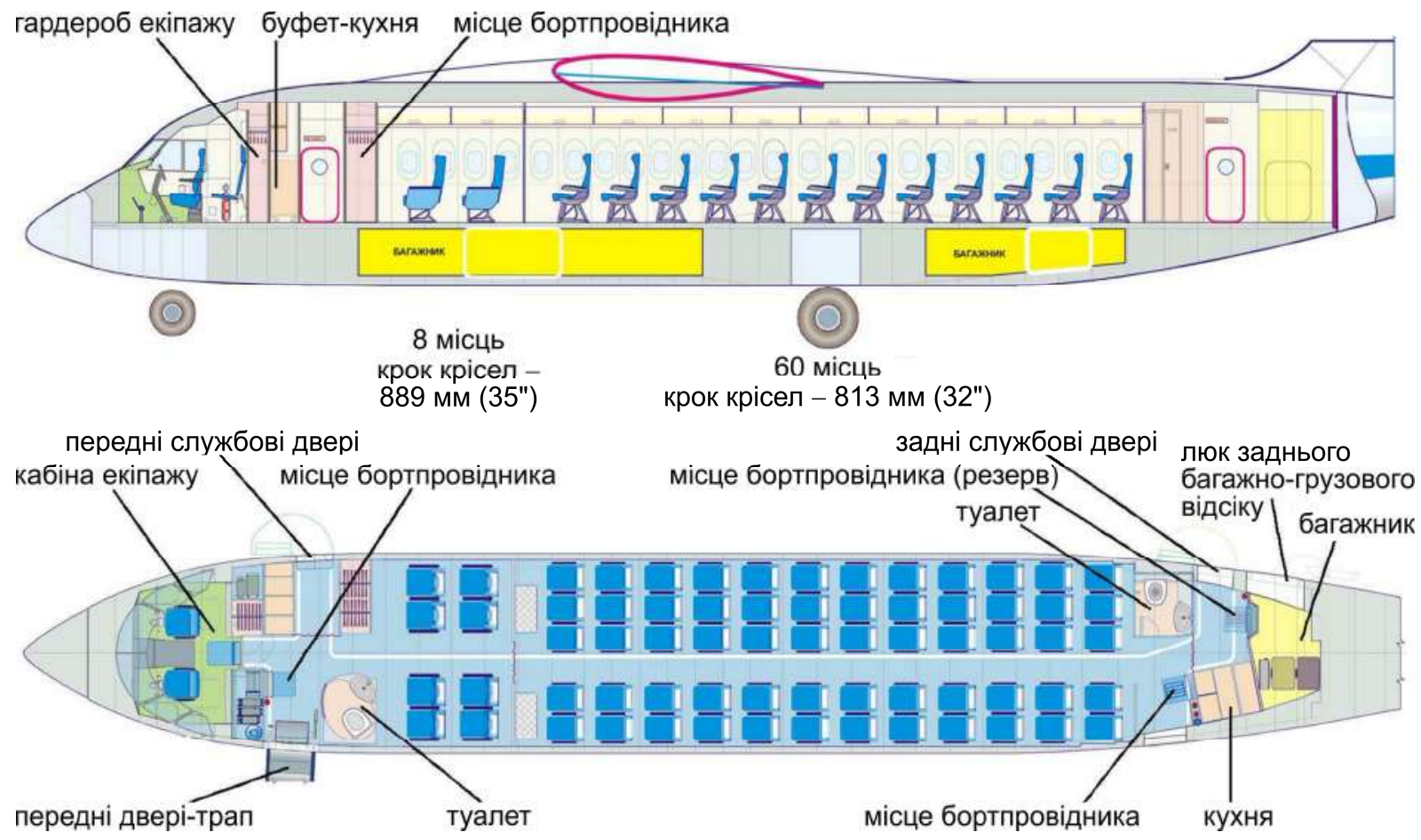

Рисунок 10 - Компонування літака Ан-148 на 68 пасажирів

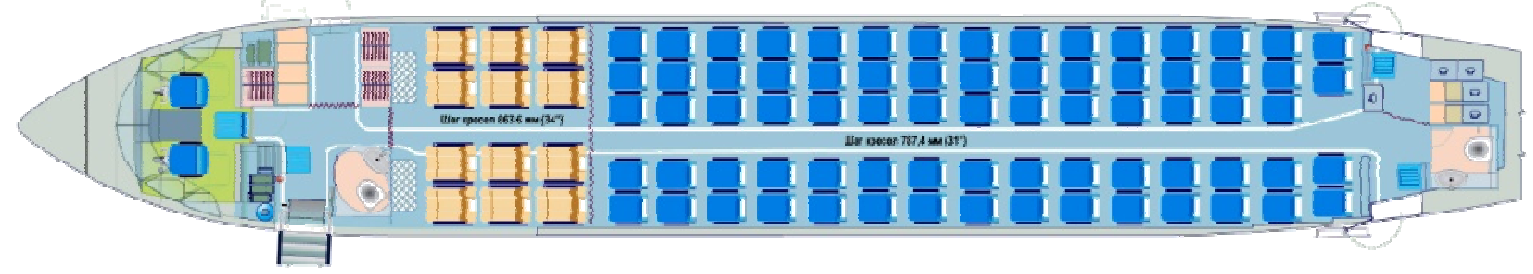

Рисунок 11 - Компонування літака Ан-158 на 86 пасажирів у двокласному компонуванні

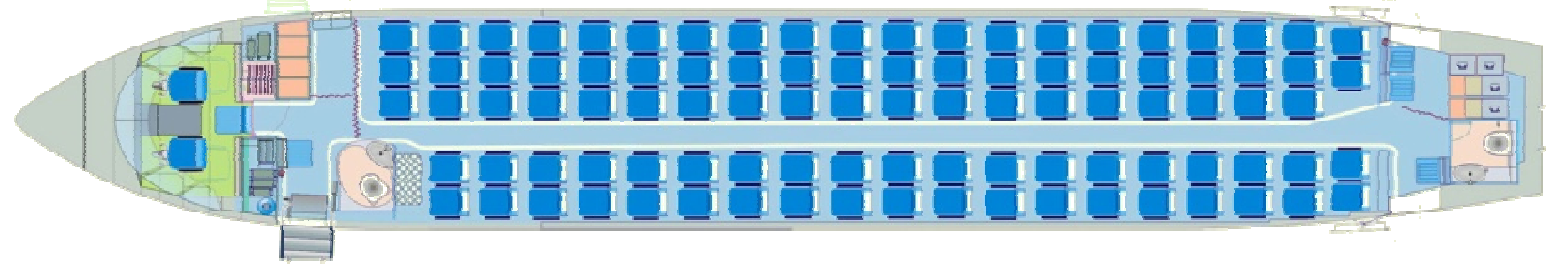

Рисунок 12 - Компонування літака Ан-158 на 97 пасажирів в однокласному компонуванні

\section{Аварійно-рятувальне устаткування}

На літаках Ан-148-100/Ан-158 встановлено систему аварійнорятувального устаткування відповідно до норм льотної придатності АП-25. До складу аварійно-рятувального устаткування входять: крісла пасажирські, крісла пілотів, візир, крісло інспектора, крісло бортпровідника по 8 шпангоуті (шп.), крісла бортпровідників по 37 і 39 шп., поручні, колиски дитячі, канати, сокира, світлова доріжка, жилети рятувальні, плоти рятувальні, колиски дитячі рятувальні, електромегафон, скоба біля передніх вхідних дверей, поручень над 
кріслом бортпровідника на 8 шп., поручень біля вхідних дверей, написи й піктограми, обмежники дверних прорізів, ремені дитячі, вставки для повних пасажирів, демонстраційні комплекти та щитки водозахисні.

Конструкція аварійно-рятувального устаткування не має таких особливостей і частин, які, як показав досвід, створюють аварійні умови або є ненадійними. Придатність і довговічність матеріалів, використаних для виготовлення деталей аварійно-рятувального устаткування, поломка яких може негативно вплинути на безпеку, визначена за досвідом експлуатації сертиорікованих літаків марки «Ан».

Забезпечена перевірка й огляд основних елементів конструкції аварійнорятувального устаткування, заміна складових частин, що звичайно потребують заміни, регулювання й змащення, необхідних для підтримки льотної придатності. Умови й технологія огляду кожного виробу відповідають інтервалу цього огляду.

Кожне крісло, поясний прив'язний ремінь, прив'язна система та прилеглі частини літака на кожному місці, призначеному для розміщення людей під час зльоту й посадки, спроектовані так, щоб людина, що правильно використовує ці засоби, не отримала б серйозної травми при аварійній посадці в результаті дії інерційних сил.

Усі крісла оснащені енергопоглинаючими опорами, які розраховані на підтримку рук, плечей, голови й хребта, оснащені комбінованими прив'язними системами, що складаються із поясних і плечових ременів з одноточковими приводами розстібання. Спинки усіх пасажирських крісел забезпечують стійку опору для рук і дозволяють людям зберігати рівновагу під час пересування по проходу при помірній бовтанці. Крім того, із цією же метою виконані поглиблення в конструкції багажних полиць.

Кожний виступаючий предмет, який може травмувати людей, що сидять або пересуваються в літаку в умовах нормального польоту, має м'яку оббивку.

Табло, що повідомляють про те, коли мають бути застебнуті ремені на кріслах, установлені на панелях індивідуального обслуговування пасажирів над кожним блоком крісел. Табло включаються й виключаються з кожного крісла пілота, і у включеному стані легко читаються кожною людиною, що сидить у пасажирській кабіні, при всіх можливих умовах освітлення кабіни.

Поверхня підлоги всіх приміщень, які в експлуатації можуть стати мокрими, має килимове покриття й лінолеум, які мають протиковзні властивості.

Кабіна екіпажу й пасажирські салони у всіх варіантах експлуатації літака оснащені аварійними виходами та світловим маркуванням аварійних виходів і шляхів евакуації, що забезпечують швидку евакуацію при аварійній посадці 3 урахуванням можливості пожежі на літаку.

Кожний аварійний вихід для пасажирів легко доступний для них і розташований там, де він буде найбільш ефективним засобом для евакуації пасажирів.

Аварійні виходи для пасажирів (передні вхідні двері-трап і задні вхідні двері на лівому борту й обидві службові на правому борту) виконані у вигляді рухомих дверей, що відкриваються назовні. Аварійні виходи для екіпажа виконані у вигляді кватирок ліхтаря, що скидається (правої) і зсувається (лівої). Усі аварійні виходи забезпечують безперешкодний вихід назовні, що підтверджено результатами демонстрації аварійної евакуації при сертифрікаційних наземних випробуваннях літака. 
Кожний аварійний вихід відкривається зсередини й зовні. Забезпечена можливість відкриття кожного аварійного виходу при відсутності деформації фюзеляжу.

Засоби відкриття аварійних виходів прості, очевидні для використання й не потребують прикладання надмірно великих зусиль.

Кватирки ліхтаря кабіни екіпажу відкриваються одним рухом, після чого ліва кватирка зрушується назад, а права знімається усередину.

Зведення до мінімуму ймовірності заклинювання аварійних виходів у результаті деформації фюзеляжу при посадці з невеликою аварією забезпечено за допомогою зазорів між конструктивними елементами дверей і люків і оточуючою їх конструкцією фрюзеляжу, а також виключенням можливості защемлення елементів механізмів засування. Забезпечена достатня міцність і твердість окантовок прорізів у фюзеляжі для сприйняття навантажень.

Кожний аварійний вихід для пасажирів, засоби підходу до нього й засоби його відкриття мають добре помітне маркування.

Розташування кожного аварійного виходу для пасажирів позначені світловим табло й забезпечують його розпізнавання на відстані, яка дорівнює ширині кабіни.

Передбачена система підлогового маркування шляху аварійного покидання (світлова доріжка) уздовж поздовжнього й поперечних проходів до аварійних виходів і світлові табло позначення аварійних виходів, що розташовані на такій висоті від підлоги, що допомагають людям знайти виходи в умовах густого диму.

Розташування кожного аварійного виходу для пасажирів позначено табло, які можуть бачити люди при їхньому наближенні по основному поздовжньому проходу для пасажирів.

На літаку встановлена система аварійного освітлення, що не залежить від основної системи освітлення та має свої власні джерела енергопостачання.

Система аварійного освітлення містить світлові табло розташування й маркування аварійних виходів, джерела загального освітлення кабіни, внутрішнє освітлення зон аварійних виходів і розташоване поблизу підлоги маркування шляху евакуації та зовнішнє аварійне освітлення.

На літаку встановлено літакову переговорну гучномовну систему, яка працює незалежно від мережі оповіщення пасажирів, та забезпечує двосторонній зв'язок між кабіною екіпажу й кожним пасажирським салоном у транспортній кабіні. Вона легкодоступна для негайного використання з кожного 3 робочих місць пілотів у кабіні екіпажу.

Переговорна гучномовна система забезпечує іï використання з робочих місць бортпровідників так, що всі аварійні виходи на рівні підлоги в кожному вестибюлі можуть оглядатися з робочих місць цих бортпровідників, має систему звукового й візуального попередження для виклику льотним екіпажем бортпровідників і бортпровідниками льотного екіпажу. При цьому система попередження забезпечує чітке розпізнавання звичайного й аварійного викликів. Переговірна гучномовна система забезпечує двосторонній зв'язок на землі між наземним персоналом і обома членами екіпажу.

Літак оснащено одним портативним мегафоном 3 автономним живленням, який легкодоступний зі звичайного крісла бортпровідника, безпосередньо відповідального за аварійну евакуацію пасажирів. Мегафон розташований у хвостовій частині пасажирської кабіни. 
На літаку $є$ місця установки й засоби кріплення аварійних медичних аптечок АБ-50 (2 шт.) для надання першої медичної допомоги в польоті і в аварійній ситуації на землі. Аптечки розташовані в легкодоступних для бортпровідника місцях у гардеробі біля крісла бортпровідника.

При проведенні польотів над пустельними, арктичними або тропічними районами на літаку забезпечена можливість розміщення спорядження із засобами життєзабезпечення людей і аварійної сигналізації, відповідними до умов району, над яким здійснюється політ. Для розміщення й кріплення цього спорядження визначені спеціальні легкодоступні місця в багажних полках пасажирського салону.

У кабіні екіпажу встановлено одну аварійну сокиру.

Літак Ан-148-100 здійснює пасажирські перевезення над великими водними просторами. У конструкції літака прийняті всі практично здійсненні конструктивні заходи, сумісні із загальними характеристиками літака, які зводять до мінімуму ймовірність того, що при аварійній посадці на воду поведінка літака викличе безпосереднє травмування людей або не дозволить їм покинути літак. Для цього забезпечена місцева й загальна статична міцність конструкції фрюзеляжу літака, включаючи вхідні й службові двері, багажні двері й люки, для сприйняття ймовірних зовнішніх гідростатичних тисків, що виникають при посадці літака на водну поверхню. Забезпечено статичну міцність усіх крісел для розміщення людей на літаку, їх прив'язних систем і вузлів їх кріплень до конструкції літака.

Для виключення ймовірності травмування людей при дії перевантажень все устаткування транспортної кабіни й кабіни екіпажу, жорстко закріплене або зашвартоване. Вантажі й багаж, що розташовані на одному рівні з людьми в задньому багажно-вантажному відсіку, зашвартовані для виключення небезпечного зрушення вантажів.

Літак скомпонований, виходячи з вимог забезпечення можливості евакуації пасажирів при аварійній посадці, і має достатні проходи уздовж транспортної кабіни й до аварійних виходів.

Для правильної поведінки в аварійній ситуації й використання аварійнорятувальних засобів розроблено оригінал-макет інструкції з безпеки, що дає пасажирам інформацію про необхідні дії у випадку змушеної посадки літака на водну поверхню.

При припустимо можливому стані водної поверхні час знаходження літака на плаву і його збалансоване положення дозволять людям покинути літак і зайняти місця в рятувальних плотах. Літак із відкритими двома зовнішніми дверми після евакуації людей тримається на плаву до занурення крила у воду, у якому розташовані порожні паливні баки після зливу палива перед посадкою на воду, близько 18,5 години. Час для евакуації пасажирів з літака, визначений за умови занурення літака до рівня поверхні підлоги біля передньої вхідної і службової дверей при передньому центруванні літака i на який можна розраховувати, становить 3,5 хв. Таким чином, час знаходження літака на плаву і його збалансоване положення дозволять людям покинути літак і зайняти місця в рятувальних плотах. В аварійних виходах, де прорізи розташовані нижче ватерлінії, передбачено встановлення водозахисних щитків, що перешкоджають потраплянню води в кабіну при відкритих дверях. Прив'язний фал, що закріплюється біля аварійного виходу, сприяє пасажирові потрапити у рятувальний пліт. 
Необхідне рятувальне устаткування, що використовується екіпажем в аварійній ситуації, легкодоступне. Місця його розміщення розташовуються так, щоб до устаткування забезпечувався прямий доступ, а його розміщення було очевидним. Рятувальне устаткування екіпажу захищене від випадкового ушкодження.

Рятувальні плоти розміщені близько виходів, через які вони можуть бути спущені при аварійному приводненні. Рятувальні жилети розміщені в межах легкої досяжності для кожної сидячої людини. Кількість плотів достатня у випадку втрати одного плоту для розміщення всіх пасажирів і членів екіпажу. Місця розміщення кожного рятувального плоту забезпечують швидке його від'єднання й зняття для використання через запропоновані аварійні виходи. Плоти закріплені швартовими ременями, що виключають їх зрив в умовах аварійної посадки. Плоти мають буксирувальні й прив'язні фрали, призначені для втримання плотів близько літака, а також засоби, що відокремлюють його при повному затопленні літака.

Аварійний радіомаяк далекої дії розташований біля дверей у кабіні екіпажу. Він має бути взятий одним із пілотів для використання на одному із плотів при аварійному приводненні.

У такий спосіб на літаку Ан-148-100 (моделі Ан-148-100А, Ан-148-100B, Ан-148-100Е) типової конструкції в аварійно-рятувальному устаткуванні прийняті всі практично здійсненні конструктивні заходи для порятунку пасажирів і членів екіпажу у всіх можливих аварійних ситуаціях, при аварійній посадці на землю й при аварійному приводненні.

\section{Двері, люки, ліхтар кабіни пілотів, вікна}

Фюзеляж має систему дверей і люків. Усі двері і кришки люків відкриваються назовні (рисунок 13). При цьому навіска всіх дверей і кришок люків (крім люка аварійного покидання літака в польоті) виконана таким чином, що при дії надлишкового тиску усередині фрюзеляжу всі вони працюють як заглушки із точковим обпиранням по поперечних балках окантовок.

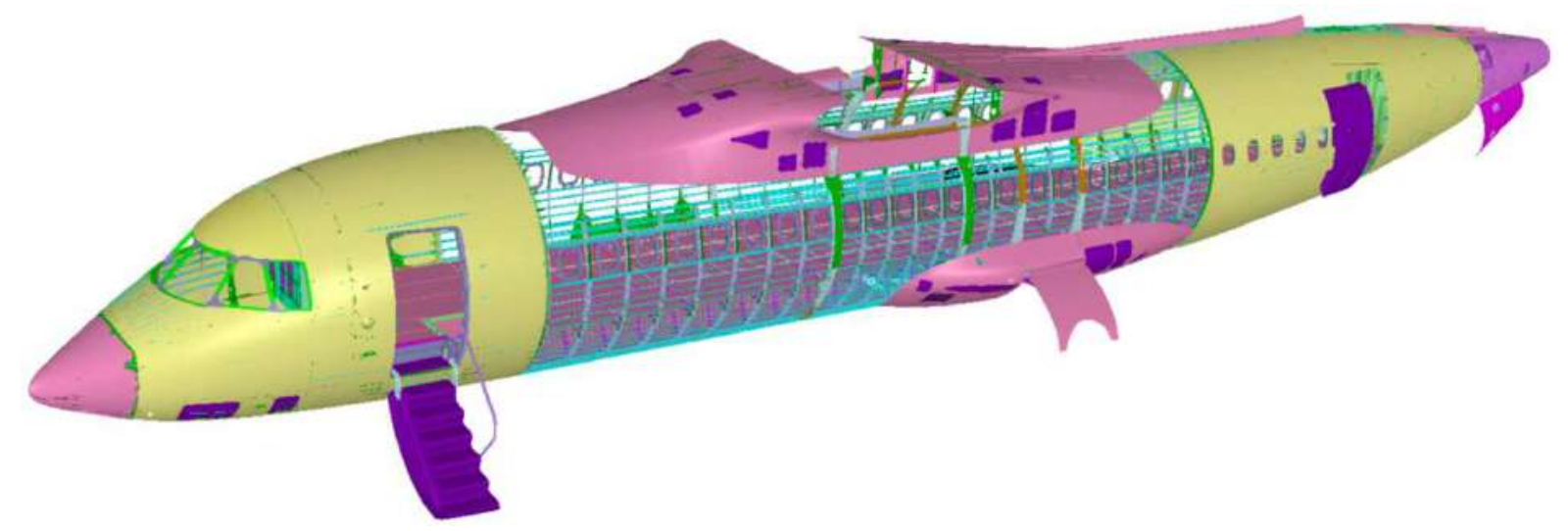

Рисунок 13 - Фрагмент моделі конструктивно-силової схеми фююзеляжу літака Ан-158

Двері і кришки люків - каркасної конструкції, утворені поперечними і поздовжніми балками, обкантовкою, а також обшивкою, що виходить на контур фрюзеляжу і сприймає надлишковий тиск. 
Передні вхідні двері виконані у вигляді трапа (див. рисунок 13). У відкритому положенні вони опираються на два вузли навіски на порозі і утримуються двома підкосами без обпирання на землю.

Двері і кришки люків мають засоби для запобігання їх відкриттю в польоті в результаті механічної відмови будь-якого одного елемента конструкції. Вони спроектовані таким чином, щоб у польоті як 3 незагерметизованою, так $\mathrm{i}$ із загерметизованою кабіною, їх відмикання з повністю закритого, замкненого і застопореного положення було практично неймовірним. У конструкції дверей передбачені засоби для запобігання відкриттю дверей у польоті внаслідок ненавмисних дій людей. Крім того, передбачені конструктивні заходи для зведення до мінімуму можливості навмисного відкриття дверей в польоті.

Механізми замикання і стопоріння спроектовані так, щоб при всіх варіантах навантаження літака в польоті й на землі при замкнених дверях були відсутні сили або моменти, що спрямовані на відкриття замків. При цьому виключена можливість відмикання замків при знаходженні стопорів у положенні, що стопорить.

На посту керування дверима передбачено виразний засіб керування дверима для вказівки, що всі необхідні дії щодо закриття, замикання й стопорінню дверей виконані. У кабіні екіпажу передбачені візуальні засоби сигналізації, а також і звукова сигналізація, що попереджають пілотів про те, що будь-які двері не повністю закриті, замкнені й застопорені.

Ліхтар кабіни пілотів розташований у верхній частині відсіку Ф-1 між шпангоутами 2 - 6 (рисунок 14).

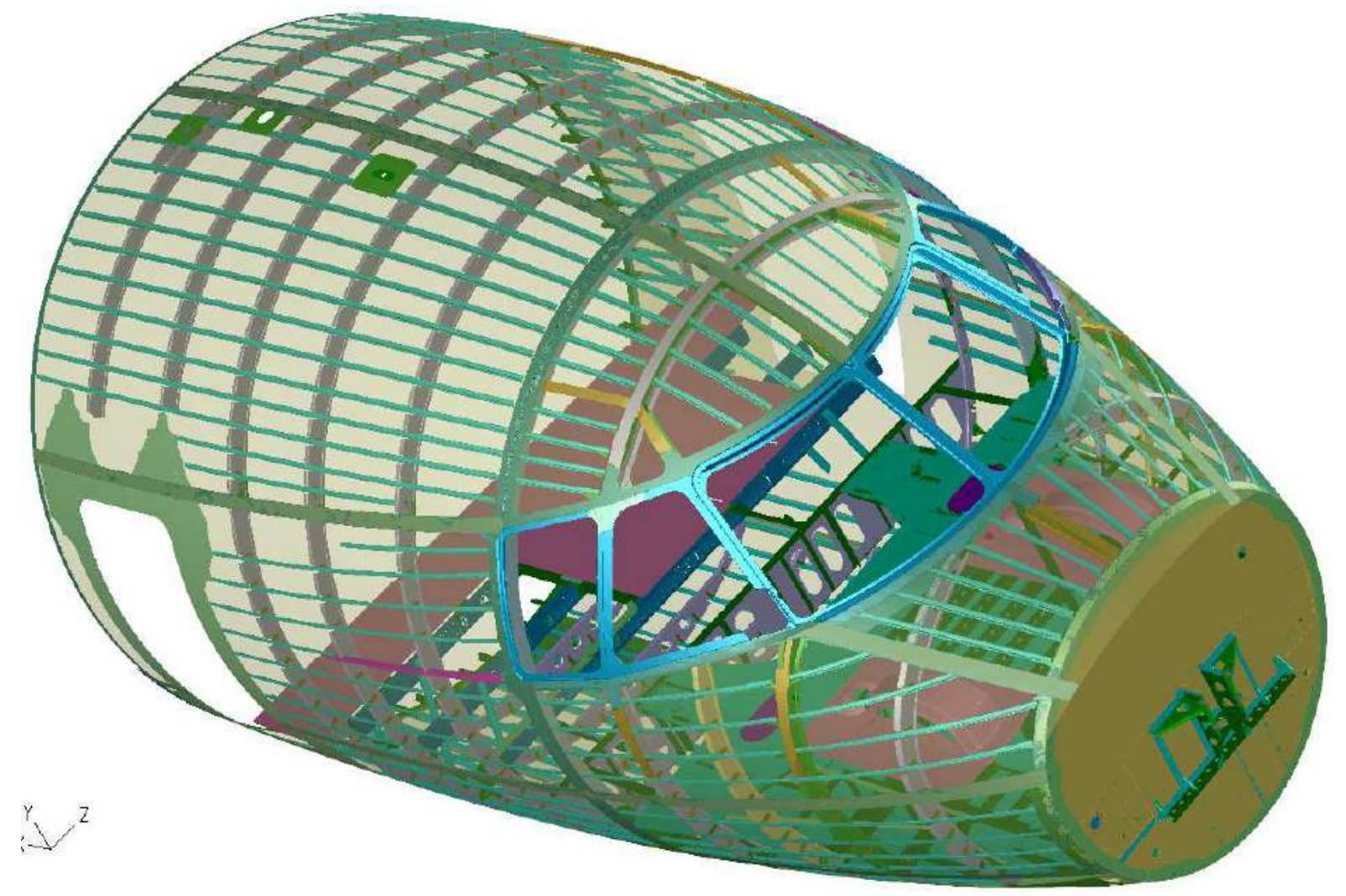

Рисунок 14 - Фрагмент моделі конструктивно-силової схеми відсіку Ф-1 фюзеляжу літака Ан-158 
Каркас ліхтаря являє собою суцільнозварну просторову стрижневу конструкцію, виконану із профрілів і поковок матеріалу 30ХГСА (рисунок 15).

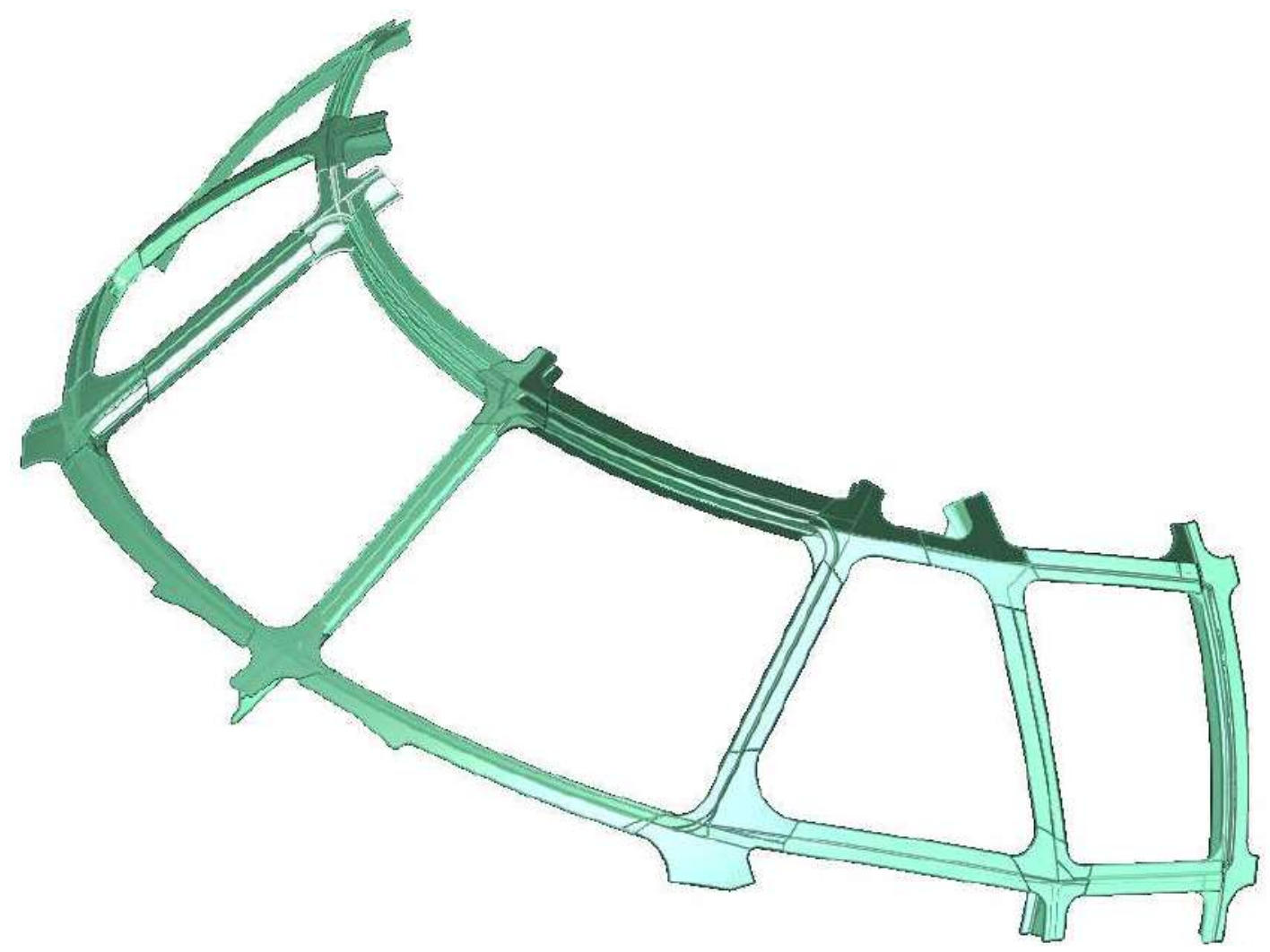

Рисунок 15 - Каркас ліхтаря кабіни екіпажу

Ліхтар кабіни екіпажу забезпечує досить широкий, безперешкодний і неспотворений огляд екіпажу, що дозволяє безпечно виконувати всі маневри в межах експлуатаційних обмежень, включаючи рулювання, зліт, захід на посадку і посадку.

За наявності опадів передбачені пристрої, які забезпечують чистоту ділянки лобового скла для того, щоб обидва пілоти мали широкий огляд по траєкторії польоту при нормальному положенні літака.

Передбачені засоби, що запобігають запотіванню внутрішніх сторін панелей лобового скла і вікон на площі, достатній для збереження огляду. Внутрішні панелі віконного скла виготовлені з матеріалу, що не розбивається на осколки. Лобове скло і елементи конструкції ліхтаря, що перебувають перед робочими місцями пілотів, витримують регламентований удар птаха відповідно до норм АП-25 [1].

По лівому й правому борту розташовані вікна пасажирського салону (рисунок 16).

Вікна (рисунок 17) спроектовані на навантаження від максимального перепаду тиску в пасажирському салоні в комбінації 3 критичним аеродинамічним тиском і температурою.

У штатній експлуатації надлишковий тиск, аеродинамічне і температурне навантаження, що сполучаються, сприймаються тільки зовнішнім склом, внутрішнє скло включається в роботу тільки у випадку руйнування зовнішнього скла. 


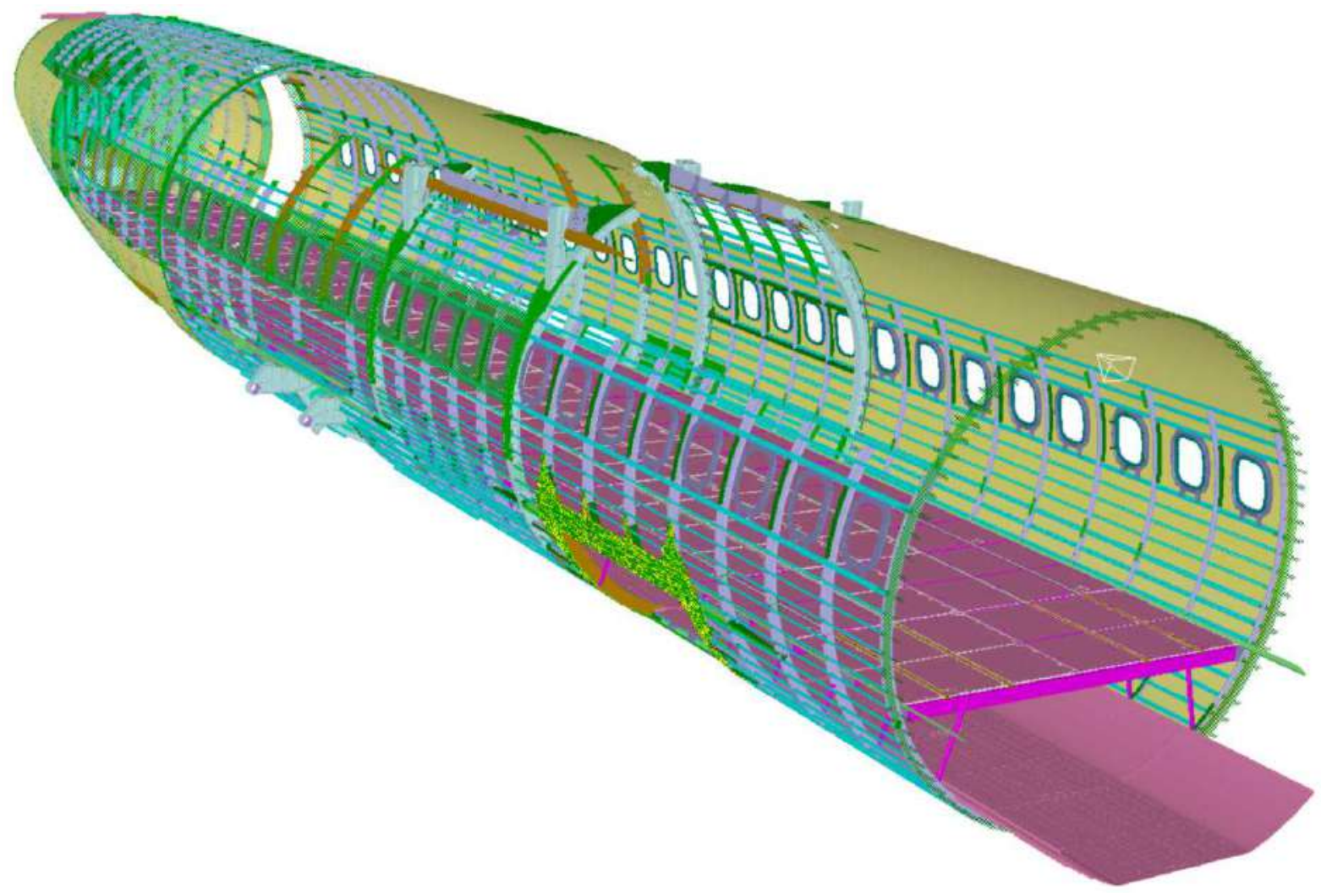

Рисунок 16 - Фрагмент моделі конструктивно-силової схеми відсіків фюзеляжу регіонального пасажирського літака Ан-158

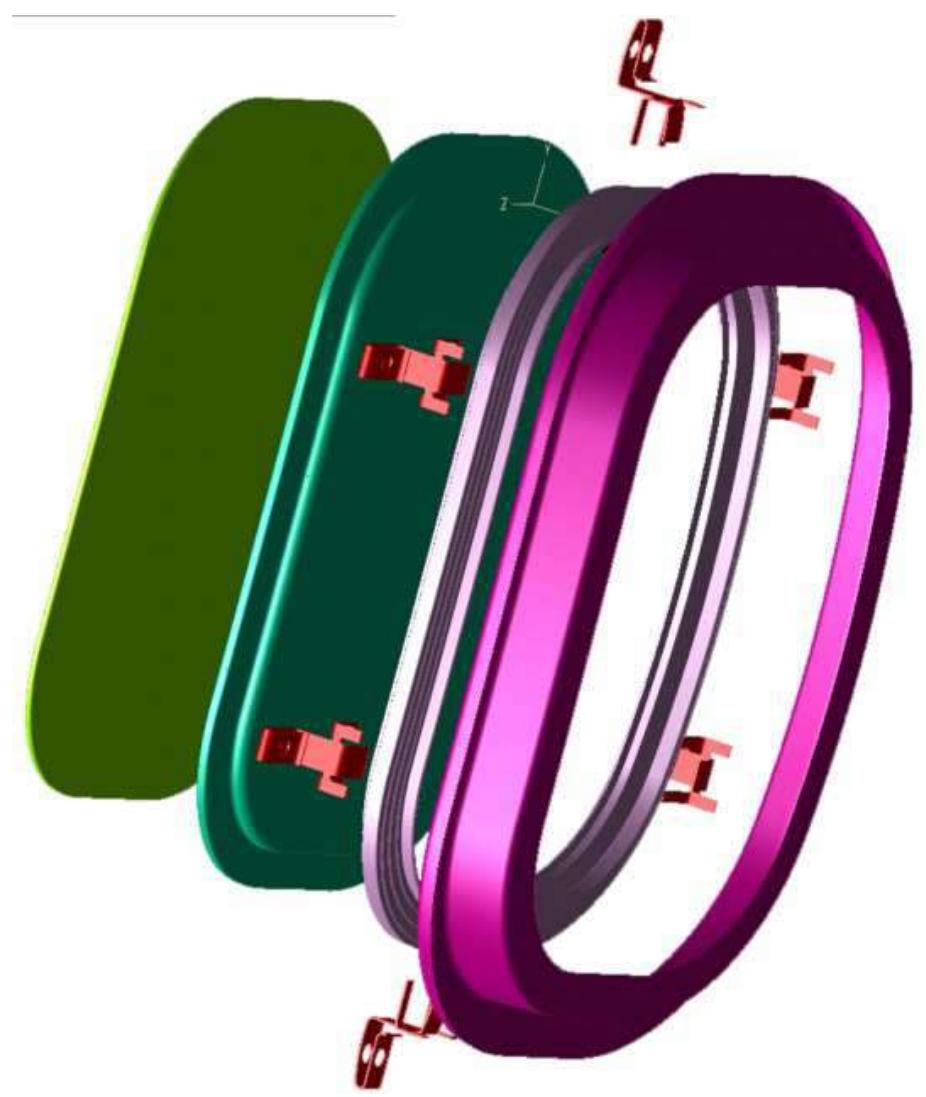

Рисунок 17 - Модель вікна пасажирського салону 
Для забезпечення відповідності конструкції планера регіонального пасажирського літака вимогам розділу D (проектування та конструкція) AП-25 [1] виконано комплекс науково-технічних і проектно-конструкторських робіт:

- Літак Ан-148. Зведені матеріали щодо статичної міцності крила. $\mathrm{G}=36,4$ т (Книга 1).

- Літак Ан-148. Розрахунок на міцність поперечних стиків крила.

- Літак Ан-148. Розрахунок на міцність центроплана.

- Літак Ан-148-100. Кесон крила. Аналіз напружено-деформованого стану та міцності нервюр КЧК по вузлах навішування закрилків і елеронів.

- Літак Ан-148-100. Кесон крила. Аналіз напружено-деформованого стану та міцності нервюр КЧК по вузлах навішування пілонів МДУ.

- Літак Ан-148. Розрахунок надлишкового тиску палива в баках-кесонах крила.

- Літак Ан-148-100. Кесон крила. Аналіз напружено-деформованого стану кесона крила методом скінченних елементів (з 01 - 01 по 01 - 03).

- Літак Ан-148-100. Кесон крила. Аналіз напружено-деформованого стану серійного крила методом скінченних елементів (NASTRAN).

- Літак Ан-148-100. Порівняльний аналіз розрахункових і експериментальних даних НДС кесона крила.

- Літак Ан-148-100. Розрахунок кесона крила з регламентованими ушкодженнями на залишкову міцність.

- Літак Ан-148-100. Оцінювання міцності бака-кесона центроплана для випадку аварійної посадки відповідно до вимог 25.963 (d) СБ-148.

- Дослідження за МСE стійкості зразків монолітних панелей крила літака $\mathrm{AH}-148-100$.

- Розрахунок коефіцієнтів переходу від теоретичних мас поздовжнього набору кесона крила до практичних мас агрегатів крила.

- Літак Ан-148-100. Пілон навішування МДУ. Аналіз напруженодеформованого стану кесона пілона методом скінченних елементів (для серії).

- Літак Ан-148. Носова частина крила. Розрахунок на статичну міцність.

- Літак Ан-148. Носок, що відхиляється. Розрахунок на статичну міцність.

- Літак Ан-148. Інтерцептори. Розрахунок на статичну міцність. Частина 1.

- Літак Ан-148. Хвостова частина крила. Розрахунок на статичну міцність.

- Літак Ан-148. Елерон. Розрахунок на статичну міцність.

- Вибір варіанта моделювання тришарових конструкцій з композиційних матеріалів у MSC/NASTRAN. Розрахунки механізації крила 3 ушкодженнями, що допускаються до вильоту 3 позабазового аеродрому.

- Літак Ан-148-100. Обґрунтування відповідності статичної міцності конструкції фрюзеляжу і обладнання, встановленого в фюзеляжі, вимогам СБ-148.

- Літак Ан-148-100. Обґрунтування відповідності статичної міцності герметичної кабіни фюзеляжу вимогам СБ-148.

- Літак Ан-148-100. Обґрунтування відповідності статичної міцності конструкції фрюзеляжу в разі аварійної посадки на землю вимогам СБ-148.

- Літак Ан-148-100. Обґрунтування відповідності статичної міцності конструкції фюзеляжу та лобового скла в разі зіткнення з птахом вимогам СБ-148. 
- Літак Ан-148-100. Обґрунтування відповідності статичної міцності конструкції фюзеляжу при його пошкодженні нелокалізованими уламками маршових двигунів і двигуна допоміжної установки вимогам СБ-148.

- Літак Ан-148-100. Обґрунтування відповідності статичної міцності стикових вузлів фрюзеляжу вимогам СБ-148.

- Літак Ан-148-100. Обґрунтування відповідності статичної міцності конструкції фрюзеляжу і обладнання, встановленого в фрюзеляжі, виконаних з лиття, вимогам СБ-148.

- Літак Ан-148-100. Обґрунтування відповідності додаткових коефріцієнтів безпеки для елементів конструкції фюзеляжу, виконаних із композиційних матеріалів, і прийнятих розрахункових характеристик композиційних матеріалів, застосованих у конструкції фрюзеляжу, вимогам СБ-148.

- Літак Ан-148-100. Оцінка залишкової міцності конструкції фрюзеляжу.

- Літак Ан-148-100. Обґрунтування відповідності статичної міцності засобів фріксації бортового обладнання, в кабіні екіпажу і транспортній кабіні вимогам СБ-148.

- Літак Ан-148-100. Обґрунтування відповідності статичної міцності конструкції крісел пілотів, інспектора, бортпровідників і пасажирів, їх прив'язаних систем і вузлів установки вимогам СБ-148.

- Літак Ан-148-100. Висновок про відповідність конструкції пасажирських крісел, їх прив'язаних систем і вузлів кріплення вимогам СБ-148 у частині динамічної міцності і травмобезпечності.

- Літак Ан-148-100. Обґрунтування вибору точок на конструкції фюзеляжу, для виконання ударів при проведенні динамічних випробувань на випадок зіткнення з птахом відповідно до пп. 25.571 (е) (1), 25.631,25.775 (b), (c) СБ-148.

- Літак Ан-148-100. Обґрунтування відповідності статичної міцності конструкції фрюзеляжу при руйнуванні шин опор літака вимогам СБ-148.

- Літак Ан-148-100. Оцінка жорсткості конструкції пристосування для випробування двері в кабіну екіпажу на стійкість до насильницького вторгнення.

- Літак Ан-148-100. Обґрунтування відповідності статичної міцності панелей і поперечних балок транспортної кабіни після впливу високих температур вимогам СБ-148.

- Літак Ан-148-100. Обґрунтування відповідності статичної міцності і втомної міцності рамок електрообігрівного скла ТСК 008У.01.000, встановленого на ліхтарі кабіни пілотів.

- Літак Ан-148-100. Обґрунтування відповідності статичної міцності конструкції крісел пілотів, інспектора, бортпровідників, їх прив'язаних систем, вузлів установки і конструкції фююеляжу в зоні установки крісел вимогам СБ-148.

- Оцінка міцності від розльоту нелокалізованих уламків ДСУ (допоміжної силової установки), яка встановлюється на протипожежному крані.

- Літак Ан-148-100 (моделі Ан-148-100A, Ан-148-100B, Ан-148-100E). Обґрунтування відповідності статичної міцності, засобів фріксації бортового обладнання в кабіні екіпажу і транспортної кабіні вимогам СБ-148. Інженерний аналіз.

- Літак Ан-148-100 (моделі Ан-148-100А, Ан-148-100В, Ан-148-100E). 
Обґрунтування відповідності статичної міцності конструкції крісел пасажирів, їх прив'язних систем і рейок під установку крісел вимогам СБ-148. Інженерний аналіз.

- Літак Ан-148-100 (моделі Ан-148-100A, Ан-148-100В, Ан-148-100Е). Обґрунтування відповідності статичної міцності засобів фріксації знову встановленого обладнання в кабінах літака вимогам СБ-148. Інженерний аналіз.

- Літак Ан-148-100 (моделі Ан-148-100А, Ан-148-100В, Ан-148-100Е). Обґрунтування відповідності статичної міцності багажних полиць, доопрацьованих по с/з. 148.01.02.1091.131, вимогам СБ-148.

- Літак Ан-148-100 (моделі Ан-148-100A, Ан-148-100В, Ан-148-100E). Висновок про відповідність конструкції літака Ан-148-100 (моделі Ан148-100A, Ан-148-100B, Ан-148-100Е) із встановленими в ньому кріслами фрірми GEVEN вимогам СБ-148 у частині динамічної міцності і травмобезпечності пасажирів (монокласне компонування на 83 пасажирських місця).

- Літак Ан-148-100ЕМ. Обґрунтування відповідності статичної міцності конструкції пасажирських крісел і дивана, прив'язних систем і вузлів їх кріплення і конструкції фюзеляжу в зоні установки крісел і дивана вимогам СБ-148. Інженерний аналіз.

- Інженерний аналіз щодо відповідності неметалічних матеріалів, що застосовуються в типових конструкціях інтер'єру літака Ан-148-100 (моделі Ан-148-100A, Ан-148-100B, Ан-148-100Е) вимогам Сертифікаційного Базису СБ-148, пункти 25.853 (a), 25.853 (d) і 25.853 (e).

- Висновок про відповідність конструкції пасажирських крісел, їх прив'язних систем і вузлів кріплення вимогам СБ-148 у частині динамічної міцності і травмобезпечності.

- Літак Ан-148-100 (моделі Ан-148-100А, Ан-148-100В, Ан-148-100Е). Обґрунтування відповідності статичної міцності засобів фріксації бортового обладнання в кабіні екіпажу і транспортної кабіні вимогам СБ-148.

- Літак Ан-148-100 (моделі Ан-148-100А, Ан-148-100В, Ан-148-100Е). Обґрунтування відповідності електрообладнання буфетів вимогам СБ-148.

- Літак Ан-148-100 (моделі Ан-148-100А, Ан-148-100B, Ан-148-100E). Обґрунтування відповідності статичної міцності крісел пілотів, інструктора, бортпровідників, їх прив'язних систем, вузлів установки і конструкції фрюзеляжу в зоні установки крісел вимогам СБ-148.

- Літак Ан-148-100 (моделі Ан-148-100А, Ан-148-100В, Ан-148-100E). Сертифікаційні випробування аварійно-рятувального обладнання.

- Літак Ан-148-100 (моделі Ан-148-100A, Ан-148-100B, Ан-148-100E). Сертифрікаційні вогневі випробування елементів конструкції інтер'єру пасажирської кабіни і кабіни.

- Літак Ан-148-100 (моделі Ан-148-100А, Ан-148-100B, Ан-148-100Е). Обґрунтування відповідності заходів щодо забезпечення безпеки під час аварійної посадки на воду вимогам СБ-148.

- Літак Ан-148-100 (моделі Ан-148-100А, Ан-148-100B, Ан-148-100E). Оцінка відповідності конструкції аварійних виходів та аварійнорятувального обладнання вимогам СБ-148.

- Літак Ан-148-100 А, В, Е. Результати наземних сертифрікаційних випробувань за оцінкою аварійно-рятувального обладнання. 
- Літак Ан-148-100. Обґрунтування відповідності статичної міцності конструкції фюзеляжу i обладнання, встановленого в фююзеляжі вимогам СБ-148.

- Літак Ан-148-100. Обґрунтування відповідності статичної міцності конструкції фюзеляжу в разі аварійної посадки на землю вимогам СБ-148.

- Літак Ан-148-100. Обґрунтування відповідності статичної міцності конструкції фрюзеляжу в разі аварійної посадки на воду вимогам СБ-148.

- Літак Ан-148-100. Обґрунтування відповідності статичної міцності конструкції фююзеляжу та лобового скла в разі зіткнення з птахом вимогам СБ-148.

- Обґрунтування вибору точок на конструкції фюзеляжу, для виконання ударів при проведенні динамічних випробувань на випадок зіткнення 3 птахом відповідно до п.п.25.571 (e) (1), 25.631,25.775 (b), (c) СБ-148.

- Літак Ан-148-100. Обґрунтування відповідності статичної і втомної міцності рамок електрообігрівного скла ТСК 008У.01.000, встановленого на ліхтарі кабіни пілотів.

\section{Основні висновки щодо конструкції планера}

У конструкції планера сімейства літаків Ан-148-100/Ан-158 (фюзеляж, крило, пілони навіски силових установок і оперення) застосовано ряд нових конструктивно-технологічних рішень:

1. У фрюзеляжі розширено обсяг застосування композиційних матеріалів, включаючи балки підлоги й стійки їх кріплення до елементів конструкції фрюзеляжу.

2. Відсік допоміжної силової установки виконаний повністю із КМ.

3. Кріплення обшивки до каркаса фюзеляжу виконано за допомогою заклепок із компенсатором, що забезпечує високу якість зовнішньої поверхні та виключає необхідність фрезування головок заклепок після їхньої установки.

4. Каркас ліхтаря фюзеляжу виготовлений методом зварювання, що суттєво спростило технологію його складання.

5. Застосована двохопорна сполучена схема навіски і керування висуванням секцій передкрилка з використанням евольвентного зачеплення в приводах випуску - вбирання передкрилка по механізмах навішення у вигляді пари зубчасте колесо - зубчаста рейка.

Завдяки використанню шарнірних підшипників у місцях кріплення рейок із кронштейнами передкрилків і сергами забезпечено взаємне переміщення й поворот останніх щодо площини механізму внаслідок зміни відстані між опорами секцій передкрилка при їхньому деформуванні і вигині кесона крила під навантаженням у польоті.

Це дозволило виключити взаємне навантаження передкрилка і кесона крила через виникаючі переміщення і забезпечити надійний контакт і роботу зубчастої пари зубчасте колесо - рейка.

6. Розроблено раціональну конструкцію кесона крила 3 теоретичною поверхнею подвійної кривизни, високою технологічністю і експлуатабельністью, із забезпеченням живучості і високого ресурсу.

7. Розроблено семиланковий механізм випуску - вбирання закрилка, що забезпечує задану траєкторію висування закрилка.

8. Розроблено комбіновану конструкцію закрилка з металевою кесонною 
частиною, носовою й хвостовою частиною і дефлектором із композиційних матеріалів (KM).

9. Застосовано покриття 3 молібдену, що підвищило зносостійкість високонавантажених деталей з титанових сплавів більше ніж в 20 раз.

10. Розроблено монолітну інтегральну конструкцію інтерцепторів і елеронів із КМ.

11. Розроблено раціональну конструкцію пілона навіски маршової силової установки із забезпеченням оптимальних характеристик жорсткості для досягнення заданих характеристик флатерної безпеки, широким застосуванням композитних матеріалів у хвостовій і носовій частинах.

12. Розроблено конструкцію поясів із пресованих напівфабрикатів із двома закінцівками.

13. Розроблено інтегральну конструкцію руля напрямку і руля висоти із композиційних матеріалів.

\section{Список літератури}

1. Нормы летной годности самолетов транспортной категории (АП-25). М.: МАК, 1994. - 322 c.

2. Гребеников, А.Г. Методология интегрированного проектирования и моделирования сборных самолетных конструкций [Текст]: монографрия / А. Г. Гребеников. - Харьков: Нац. аэрокосм. ун-т «ХАИ», 2006. - 532 с.

3. Конструктивно-технологические методы повышения усталостной долговечности элементов конструкции планера самолета в зоне функциональных отверстий [Текст] / Д. С. Кива, Г. А. Кривов, В. Ф. Семенцов, А. Г. Гребеников и др. - Киев: КВИЦ, 2015. - 188 с.

4. Научные основы конструктивно-технологических методов обеспечения ресурса авиационной техники [Текст]: монография / В. А. Богуслаев, А. Г. Гребеников, Н. И. Москаленко и др. - Х.: Нац. аэрокосм. ун-т им. Н. Е. Жуковского «Харьк. авиац. ин-т», 2017. - 292 с.

\section{Reference}

1. Normy letnoj godnosti samoletov transportnoj kategorii (AP-25) [Part 25. Airworthiness Standards: Transport Category Airplanes]. - M.: MAK, 1994. - 322 p.

2. Grebenikov, A. G. Metodologija integrirovannogo proektirovanija i modelirovanija sbornyh samoletnyh konstrukcij [Methodology of integrated design and simulation of prefabricated aircraft structures]: monograph / A. G. Grebenikov. Kharkov: National Aerospace University «KhAl», 2006. - 532 p.

3. Konstruktivno-tehnologicheskie metody povyshenija ustalostnoj dolgovechnosti jelementov konstrukcii planera samoleta $\mathrm{v}$ zone funkcional'nyh otverstij [Constructive-technological methods for increasing the fatigue life of structural elements of the airframe of an airplane in the area of functional openings] / D. S. Kiva, G. A. Krivov, V. F. Semencov, A. G. Grebenikov i dr. - Kiev: Kvyts, 2015. $-188 \mathrm{p}$.

4. Nauchnye osnovy konstruktivno-tehnologicheskih metodov obespechenija resursa aviacionnoj tehniki [Scientific basis of constructivetechnological methods for providing aviation equipment resource]: monograph / V. A. Boguslaev, A. G. Grebenikov, N. I. Moskalenko etc. Kharkov: National Aerospace University «KhAl», 2017. - 292 p.

Надійшла до редакції 24.12.2018, розглянута на редколегії 27.12.2018. 


\section{Design Features of the Regional Passenger Aircraft Airframe}

The design features of the regional passenger aircraft airframe, which were introduced at the stages of developing the An-148/An-158 aircraft family, are described. The design and construction works on the airframe, which were aimed at the implementation of the airframe design concept, based on the principle of a safely damaged structure, are given. The An-148/An-158 airplanes were designed using modern computer-aided design systems. The work performed provides aeroelastic stability for all configurations and all design conditions. When creating a family of regional passenger airplanes, a number of new design and technological solutions were applied to the airframe design (fuselage, wing, pylons of powerplants and tail assembly), in particular: the scope of composite materials (CM) application was expanded, including the fuselage beamstructural elements; auxiliary power unit compartment is made entirely of $\mathrm{CM}$; fastening the skin to the fuselage frame is made using rivets with a compensator, which ensures high quality of the external surface and eliminates the need for milling the heads of rivets after their installation; the fuselage canopy frame was made by welding, which significantly simplified the assembly technology; a two-support connected hitch scheme and control of extension of the slat sections with the use of involute gearing in the slat extensionretraction drives on the hinge mechanisms in the form of a pair of gears - a gear rack; developed a rational design of the wing box with a theoretical surface of double curvature, high adaptability and operability with survivability and high lifetime; a seven-part flap extension-retraction mechanism has been developed, which provides a predetermined flap advancement path; a combined flap design with a metal torsion box part, nose and tail part and a deflector made of CM; a molybdenum coating was applied, which increased the wear resistance of high-loaded parts from titanium alloys by more than 20 times; a monolithic integral design of interceptors and ailerons from CM was developed; a rational design of a pylon of a hinge plate of a mid-flight power plant has been developed with optimal rigidity characteristics to achieve given characteristics of flutter safety, with extensive use of composite materials in the tail and nose sections; the design of caps from pressed semi-finished products with two tips has been developed; an integrated design of the rudder and elevator made of composite materials has been developed.

Keywords: regional passenger aircraft, aircraft airframe, design and construction works, passenger, emergency equipment.

\section{Відомості про авторів:}

Донець Олександр Дмитрович - Президент ДП «АНТОНОВ», м. Київ.

Двейрін Олександр Захарович - канд. техн. наук, Головний конструктор ДП «АНТОНОВ», м. Київ.

Василевський Євген Тимофрійович - канд. техн. наук, доц., заступник Головного конструктора з крила і оперення, ДП «Антонов», м. Київ, Україна.

Філь Сергій Андрійович - канд. техн. наук, Головний конструктор 3 перспективних розробок ДП «АНТОНОВ», м. Київ.

Гребеніков Олександр Григорович - д-р техн. наук, проф., зав. кафр. 103 «Проектування літаків та вертольотів», Національний аерокосмічний університет ім. М. Є. Жуковського «Харківський авіаційний інститут», Україна.

Гуменний Андрій Михайлович - канд. техн. наук, доц. каф. 103 «Проектування літаків та вертольотів», Національний аерокосмічний університет ім. М. Є. Жуковського «Харківський авіаційний інститут», Україна. 